\title{
Adjusting To Free Trade Egypt's Textile And Ready Made Garment Industry
}

Abeer Elshennawy. (E-mail: ashenawy@aucegypt.edu), American University, Cairo, Egypt

\begin{abstract}
This paper investigated the sources of competitive pressure facing the Textile and ready made garment producers in the course of trade liberalization within the framework of the free trade agreement concluded between Egypt and the European agreement. The main sources of competitive pressure and the main impediments to efficient adjustment to free trade were found to be institutional in nature namely the custom law. Competitive pressure further arises due to the recession and due to the scarcity of some inputs like skilled labor and capital.
\end{abstract}

\section{INTRODUCTION}

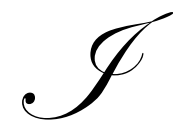

n July 2001, Egypt signed an association agreement with the European Union. Some time in the coming couple of years, Egyptian producers who have long been accustomed to operate within a highly protected domestic market will be facing competition from EU imported products at home. Most producers, however, do not expect a smooth transition to freer trade. As a result, policy makers before and during the process of negotiating this agreement have been continuously under intense pressure to abandon the whole idea or postpone liberalization.

The major concern is that competition from imports is a frequent reason for why industries become distressed. A distressed industry is one that features excess capacity, unemployment or produces inefficiently over a sustained period of time. An industry that shows signs of distress is not necessarily declining i.e. one that has lost the ability to compete over the long run. Distressed industries can be troubled due to a temporary loss of competitiveness. A permanent loss of competitiveness occurs primarily due to a rise in the relative cost of the factor for which production is most intensive in. A temporary loss in competitiveness occurs due to cyclical (temporary) factors. Among the most important of these factors are a cyclical fall in demand, overvaluation of the currency and protectionist measures in major export markets. (Patrick, 1991).

The policy response is radically different in each case. Allowing industries that has lost the ability to compete over the long run to decline is warranted and is considered one of the most important goals of trade liberalization. In contrast, in the case of troubled industries, the correct response is to prevent decline. (Patrick, 1991). The challenges are quite enormous because ideally, this process should proceed with minimal disruption to production, employment and minimum pressure on the balance of payment. In other words, with minimum adjustment costs, a condition crucial for the sustainability of trade liberalization. (Papageorgiou D., Michaely, M., and Choksi A.1991). Assessing exante whether an industry is declining or troubled, (Patrick, 1991) identifying the sources of competitive pressures facing firms and workers, understanding their response to such pressures - which is an issue vital for choosing the appropriate adjustment policy (ECC, 1988) - and determining the correct timing for liberalization are but some of the challenges awaiting policy makers and implementers.

Using a sample of 13 firms in the textile and ready made garment industry, this research will seek to explore the nature and sources of the competitive pressures that are likely to face producers as a result of trade liberalization following the implementation of the Euro-Med association agreement. In particular, it is necessary to understand how producers in this sector are planning to adjust to these competitive pressures and identify the main constraints that 
might impede efficient adjustment to free trade with special emphasis on transaction costs.

As will be explained in this paper, these constraints often imply that it is not really a matter of how much time or how long a breathing space is needed until firms and workers actually adjust, but rather what complementary reform measures and in which areas are needed to accompany trade reform. The solution might turn out to be far more complicated than merely providing a sixteen year transition period before liberalization takes place as inherent in the association agreement between Egypt and the EU. The remaining of this paper is organized as follows. Section one presents the result of the survey and section two concludes.

\section{SURVEY RESULTS}

Apart from its large contribution to employment and exports (30\% and $25 \%$ respectively) in the manufacturing sector, the textile and ready made industry performance has recently deteriorated. Between 1990 and 2001, Egypt's share of the world's exports of textiles declined from $0.5 \%$ to $0.2 \%$ while its share in the world's exports of ready made garments stagnated at $13 \%$. Moreover, the index of revealed comparative advantage in the case of textiles declined from 7 in 1990 to 2.9 in 2001 while that for ready made garment remained constant at 1.8 over the same time period. (Fawzy,2003)

It is worthwhile noting that effective protection rates are as high as $38.4 \%$ for spinning and weaving and $826 \%$ for ready made garment in 2002. (Refaat, 2003). Excess capacity reached $29.55 \%$ (of total capacity) in 1999/2000. All this provides evidence that the industry is distressed which casts doubts on the ability of firms in this sector to withstand competition from imported EU products or from imports in general. It remains to determine whether the industry suffers from structural problems - affecting its ability to compete over the long run - or from short run cyclical problems.

The association agreement recently concluded between Egypt and the EU raises one more important question and that is how producers will adjust to competition from EU imports.. However, before discussing the set of feasible adjustment strategies, it is necessary first to determine the nature of the threat posed by competition from EU imports because of the agreement and the sources of competitive pressure facing producers of the Textile and Ready Made Garment industry.

\section{The Threat}

Several factors render competition with EU imports on a quality /price basis difficult if not impossible. To some extent, these factors differ across the three main subsectors - spinning, weaving and ready made garment and according to which segment of the market - lower, middle or upper- is being considered. Since spinning and weaving is protected in Europe via tariffs imports of these products should not pose much of a threat except maybe in the upper segment. For these two subsectors as well as the Ready Made garment subsector, rules of origin that stipulate that for the product to be considered as originating in EU at least two stages of production must take place in EU, should provide enough of a safeguard. The recent devaluation of the Egyptian pound will also reduce the volume of imports.

Despite of these factors most of the firms in the sample expressed concern regarding competition from EU imports. For producers catering the lower segment, it is cheap defected or left over products that are conceived as the potential threat, while European brand names and lower cost products originating in Eastern Europe represents an additional threat for those catering the upper segment of the market.

\section{The Set Of Feasible Adjustment Strategies}

Faced with competition from imports, producers have a number of adjustment strategies opened to pursue as presented in table 1 below. These range from exit, to revitalization and finally to request of protection. Revitalization in turn comprises three options: offering a product at a better price/quality combination, searching for a new market niche and reducing factor rewards. Choosing the appropriate adjustment strategy is closely linked to market characteristics as determined by the specificity of equipment, the degree of product differentiation, scale economies 
and the separability of stages of production. (ECC, 1988). Based on this configuration, we will attempt to project the set of adjustment strategies opened for the Textile and Ready Made Garment sector.

Table 1

Adjustment Options

\begin{tabular}{|c|c|c|c|c|c|}
\hline & \multicolumn{4}{|c|}{ Revitalization } & \multirow[b]{2}{*}{ Protection } \\
\hline & Exit & $\begin{array}{l}\text { Better quality/price } \\
\text { combination }\end{array}$ & $\begin{array}{l}\text { New Market } \\
\text { Niche }\end{array}$ & $\begin{array}{c}\text { Reduced Factor } \\
\text { Reward }\end{array}$ & \\
\hline \multicolumn{6}{|l|}{ Market Characteristics } \\
\hline \multicolumn{6}{|l|}{ Equipment } \\
\hline a)For specific use & & $\mathrm{X}$ & & $\mathrm{X}$ & $\mathrm{X}$ \\
\hline b) Easily transferable & $\mathrm{X}$ & & $\mathrm{X}$ & & \\
\hline \multicolumn{6}{|c|}{ Degree of product differentiation } \\
\hline a)Very low & $\mathrm{X}$ & & & $\mathrm{X}$ & $\mathrm{X}$ \\
\hline b)High & & $\mathrm{X}$ & $\mathrm{X}$ & & \\
\hline \multicolumn{6}{|c|}{ Degree of Scale Economies } \\
\hline a)Zero & $\mathrm{X}$ & & & & $\mathrm{X}$ \\
\hline b)Considerable & & $\mathrm{X}$ & $\mathrm{X}$ & & \\
\hline \multicolumn{6}{|c|}{ Separability of stages of production } \\
\hline a)Yes & & $\mathrm{X}$ & $\mathrm{X}$ & $\mathrm{X}$ & \\
\hline b) No & $\mathrm{X}$ & & & & $\mathrm{X}$ \\
\hline
\end{tabular}

Machinery and equipment account for approximately 50\% of total fixed capital in this industry. This percentage rises to $80 \%$ in the case of knitting mills. Within the different sub sectors, machinery and equipment are specific. In knitting, machines suitable for pullovers are specific to this product. In Ready Made Garment, machines suitable for upper wear are different from bottom wear and could also vary depending on fabrics (for example those suitable for jeans are different than those suitable for other fabrics). In both knitting and Ready made garment machines designed to produce high quality products can also produce low quality products but the reverse is not true. Because equipment in this industry is highly specific, sunk cost will be high enough to deter firms from exiting. This will be true the larger the firm since this implies larger sunk costs compared to small firms. Equipment Specificity leaves firms with two adjustment strategies; revitalization and request of protection. Only, two options are possible under revitalization; offering a better price/quality combination, reduced factor rewards and to a limited extent searching for new market niches.

An industry with wide scope for product differentiation and considerable degree of scale economies like Textile and Ready Made garment offers more room to revitalize either by offering better price/quality combination or through searching for new market niches. Firms will neither exit nor request protection because of the separability of stages of production while all three options under revitalization are feasible. However, this strategy will be less likely to be followed the smaller the size of the firm since relocating one of the stages of production in anther region or country becomes difficult. (ECC, 1988). 
Given the market characteristics described above, theoretically speaking firms have two adjustment options; revitalization or request of protection. The results of the questionnaire will further aid in projecting which adjustment strategy will be pursued. More importantly, these results will help identify the constraints impeding efficient adjustment. One aspect revealed from the interviews will make both these tasks much easier. Even though highly protected, competition from imported goods is not new to this sector. Shortly after establishing free trade zone in the governart of Port Said, the industry faced problems as a result of competition from smuggled imports coming through the free zone.

\section{Impediments To Efficient Adjustment To Free Trade}

\section{Tariffs And Taxes}

One main reason why firms - especially in the lower segment of the market - could not compete with smuggled duty free imports particularly originating from China is tariffs and sales taxes on imported inputs. ${ }^{1}$ Preferential liberalization in the context of the EU agreement will create a similar situation. Generally speaking, and in light of the protectionist stance that the government continues to adhere to, competing on quality/price basis will be difficult as long as domestic producers - unlike their European counterpart cannot have access to cheaper tax-free and better quality inputs from world markets. Competitive pressure arising due to this factor will thus intensify even more as the agreement comes into force.

\section{Letters Of Credit}

Aside from tariffs and sales taxes, many other administrative complications arise when some or all of inputs have to be imported. To begin with, letters of credit has to cover $100 \%$ of the cost of imports, a requirement cited by firms as very restrictive. A recent modification to the procedural requirement for importing stipulates that the importer have to pay legalization fees for two documents (the final invoice and certificate of origin) to the Egyptian embassy in the country from which imports are being imported. These two documents must be sent directly by the foreign supplier - via mail only - to the embassy. One week to ten days elapses before this task is completed causing delay in shipping the inputs. In addition, a cost of 300 Euros or \$500-600 is paid in fees. Such fees can be well in excess of the value of small import consignments.

\section{Customs Administration}

Custom clearance procedures are costly and time consuming. Custom clearance fees are high relative to other developing and developed countries. These vary between $\$ 26-180$ per container. They are not predetermined by the law and so are frequently the subject of disputes between customer officers and importers. To avoid such disputes, importers incur (unofficial) side payments ranging from $\$ 100-130$. In addition, the time needed to complete clearance procedures is on average 10 days, which is very long compared to 3.5 days for developing countries and 2.5 days in the case of developed countries. (Helmy, O. 2003).

Because on time delivery of the final product is crucial, on time delivery of the intermediate inputs is in turn crucial. Products of the textile and ready made garments industry satisfy demand for four different seasons each year; fall, winter, spring and summer. Each season lasts for four months. Products of each season are displayed in retail outlets usually way before the season begins. Due to the short length of each season and since products convenient to the weather conditions of one are not suitable for the other on time delivery of the final product is vital. Time restrictions rise in importance as we move up market from the lower to the medium and upper segments of the market and in the case where part or all output is destined to world markets.

Given these characteristics, both physical and human asset specificity do not offer much scope for strategic holdups as much as temporal specificity does. According to Masten et al, 1999 temporal specificity arise when the different stages of production have to be ordered and coordinated to insure that output will be produced and delivered 
on time. More seriously failing to attain this objective at one stage disrupts production through out the system and consequently results in failure to deliver the final product on time.

In other words "where timely performance is critical, delay becomes a potentially effective strategy for exacting price concessions. Knowing that interruptions at one stage can reverberate through out the rest of the project, an opportunistic supplier may be tempted to seek a larger share of the gains from trade by threatening to suspend performance at the last minute. Even though the skills and assets necessary to perform the task may be fairly common, the difficulty of identifying and arranging to have an alternative supplier in place on short notice introduces the prospect of strategic holdups. Expanding Williamson's original four way classifications we refer to this latter source of holdups as temporal specificity. " ( Masten et al, 1999, p. 264)

Specifying damages in contracting although possible provides only an imperfect solution to avoid opportunism while holding buffer inventory of inputs is not always feasible under uncertain demand conditions or due to the specialized nature of some inputs. (Masten et al, 1999). In the case of textile and ready made garment industry where both demand uncertainty and the nonstandardized nature of some inputs are important, temporal specificity becomes the main source of strategic holdups by custom officials in Egypt.

Custom laws are considered a major obstacle to importing. Despite recent reforms to custom laws, custom officers still enjoy considerable discretionary power when it comes to the valuation of inputs to determine tariff charges. It is often the case that importers are charged fines if prices of imports are revised upwards. Moreover, the fines accrue to custom officials creating strong incentives for overvaluation. (Helmy, O. 2003)

When disputes arise, the importer can petition, but all three methods for resolving these disputes are slow and inefficient. These include forming a consultative committee - whose members are from inside the custom administration or from outside- arbitration or taking the case to court. Inefficiency arises mainly due to three reasons. First rules of arbitration are not clear especially when it comes to pricing because of insufficient data. In addition, the arbitrators themselves do not have enough experience dealing with problems of this sort. Second, there is no time limit for settling these disputes. Finally arbitration deals only with three kinds of cases; classification, pricing and origin of imported goods. Importers will have to take the case to court for any other problems. (Helmy, O. 2003)

It usually takes at least two months to settle disputes, sometimes this period can extend to over a year or two. To file a case, the importer will have to provide authentic importation documents, a process that takes place through the Egyptian embassy in each country from which inputs have been imported. At the same time, custom clearance cannot take place except after tariff and sales taxes are paid in full. Uncleared shipments are destroyed by custom authorities. Revaluation is therefore initially imposed as it is a matter of take it or leave it. Pressed for time, importers usually pay the amount assessed by authorities in full plus fines that are calculated as a percentage of discrepancies. Banks stand ready - through issued letters of credit- to cover the new higher value tariffs and sales taxes, but this of course leads to higher interest payments increasing the overall cost of inputs.

The main point is that given the importance of time restrictions in certain segments of the market (medium to upper) along with temporal specificity in this sector, custom law provides ample room for custom officers to exercise opportunism and consequently increases the transaction costs of import clearance.

It is worthwhile noting that importers are also in a position to exercise opportunism by providing forged purchase documents that underestimates the true value of the import consignment. If undervaluation goes undetected by customer officers, both the officer and the importer could be charged with smuggling and can be imprisoned as a result. To avoid these charges, customer officers choose to revise upwards the value of the consignment. ${ }^{2}$

Although the ministry of finance has launched an ambitious plan to revise the custom law - law 66 of the year 1963- and reform the system (Helmy, O. 2003), the plan did not touch directly on problems of revaluation and dispute settlement. These problems are therefore here to stay. Moreover, the plan itself requires a considerable 
amount of time to come into force. Also, the financial and human resources needed to implement it are quite substantial.

The agreement will come to the rescue for those producers who can take advantage of duty free inputs from the EU. All will depend on the elasticity of substitution. However, the fact that this sector is heavily protected even in Europe itself, suggests that trade diversion might not greatly improve competitiveness. That is, even if it places Egyptian producers on equal footage with their European counterpart who source part or all of their inputs from the European market, it might not improve their position vis a vis Chinese producers. (Coarse yarn is mainly imported from India and Pakistan, wool from UK and Turkey)

\section{The Recession}

Beside competition from smuggled imports, the recession added to the difficulties facing producers. These two factors together with the presence of a large number of small producers decreased the scope of exploiting economies of scale in order to reduce overhead cost. The decreasing number of retailers and wholesalers, as the public sector, which provided the main outlet for the products of this sector contracted, contributed to further reduction in the size of the market. Integrating forward into retail increases the risk that firms have to bear and the lack of specialized sales workforce rendered own retail outlets difficult to operate.

Because the sources of competitive pressure are more or less the same regardless of whether imports are smuggled from China or imported duty free from the EU, it is natural to expect that the response with also be the same. Therefore, understanding how producers reacted to competition from Chinese products - under the above circumstances - will shed some light on the adjustment strategies that will be pursed when the agreement comes into force, as well as the constraints that might impede efficient adjustment.

\section{Adjustment To Competition From Smuggled Imports}

Since the high cost of imported inputs rendered adjustment based on offering a better price/quality combination difficult while reducing factor rewards was infeasible, revitalization through searching for new market niches either in the domestic or foreign market or both was a common adjustment strategy pursued by many of the firms interrogated in the sample. For a number of firms searching for new market niches took the form of moving up market because it was mainly the lower segment of the market that was most vulnerable to competition from Chinese imports. Product differentiation especially under a local brand name was anther adjustment strategy.

A third adjustment strategy pursued by firms in response to competition from smuggled imports and/ or the recession was exporting. Several factors encouraged firms to follow such a strategy. First, Firms can have access to duty free inputs from world markets through the temporary admission and Drawback mechanism. Second, Large overhead cost (administrative cost, high and mid management cost, partially labor, partially electricity, land, rent, depreciation, maintenance costs, transportation), renders the larger export market better suited to exploit economies of scale. By lowering the costs of production through exporting, some producers were able to retain their share in the domestic market. Third, rather than producing a wide range of products in the domestic market, specialization in a few products made possible by sufficient export demand increased efficiency. Fourth, Overcoming problems of illiquidity which makes it difficult to receive cash payments in return for produced goods in the domestic market could also be overcome through exporting.

Fifth, securing the necessary foreign currency through exporting was important in cases where the raw material used in the production of goods for the domestic market had to be imported. (This would be particularly important the larger the share of inputs that must be imported in total inputs). Sixth, stable exchange rates eliminated exchange rate risk and so borrowing in dollars - which is only possible for exporters - becomes cheaper than borrowing in local currency since the interest rate is lower. Seventh, for others expectation of future devaluation increases Egypt's comparative advantage in this sector. 
The puzzle that remains to be resolved is how the same producers who were unable to compete with imports in the domestic market were able to compete on world markets. Of course avoiding the domestic market means cutting back on all the previously mentioned costs. An industry that is overburdened with taxes (tariffs, sales taxes for imported inputs, equipment and spare parts and a variety of other taxes) is certainly not in a position to compete with smuggled duty free imports coming through the free zone area of Port Said. The difficulty facing domestic producers increases even more due to the fact that these smuggled imports are subsidized at their country of origin or are left overs.

More importantly, the fact that these producers enjoy tariff exemptions in a host of countries or export under the quota system made exporting possible. Most producers export to the EU taking advantage of duty free access under the 1977 cooperation agreement, or under quotas in the USA. Subcontracting for major brand names on world markets is quite common. However, foreign buyers resort to Egyptian exporters after the quotas allocated to producers that are more efficient are used up. Success in exporting must therefore be evaluated cautiously because of the preferential treatment, which for some of firms is perceived as permanent. Sustaining such a strategy will be questionable given the phasing out of the Multifiber agreement that has already been phased out.

The liberalization taking place in this sector under the auspices of GATT agreement is not likely to adversely affect producers catering the medium and upper segment of the market. Nevertheless, exporting proves that some improvement in competitiveness was possible. It also proves that competition from smuggled imports was not the only problem facing firms in the domestic market, but rather all the previously mentioned constraints.

\section{Impediments To Efficient Adjustment Revisited}

\section{Temporary Admission And Drawback Mechanism}

Exporters are able to rebate tariff and sales taxes on imported inputs after going through the lengthy time and cost consuming procedures of the drawback and temporary admission mechanism. This is a process that involves a multitude of procedures in which several governmental bodies are involved, including the customs office, the ministry of industry, the general authority for importing and exporting and finally the administrative office of the drawback and temporary admission mechanism itself.

To be able to use the temporary admission mechanism, the producer has to provide a letter of credit from a bank covering the cost of the imported inputs (initially, only primary inputs were allowed and only recently, in June 2002 was the law modified to allow intermediate inputs in general) inclusive of tariffs and sales taxes. Anther option is importing using the assets of the company as collateral. All inputs must be totally used in the production of the exported good, i.e. firms cannot sell any of these inputs in the domestic market. (This article has also been modified in the same above date, but producers have to pay the full amount of tariffs and taxes plus a fine of $2 \%$ for every one month delay in paying these taxes.).

According to the Draw back mechanism, firms can import the necessary intermediate inputs, but have to pay upon importation and arrival of the inputs to pay in full the amount of tariff and sales taxes due on these inputs. Tariffs and sales taxes are then rebated after the authorities make sure that the goods produced using these imported inputs have been exported. Selling these inputs in the domestic market or using them in any means other than that initially specified is allowed since the taxes have been already paid in full.

Exporters face the same problems in dealing with custom administration discussed above. These problems become even more severe in the case of exporting due to the increasing importance of time restrictions, which is one the most important determinant of competitiveness on world markets. Products are displayed in retail outlets according to strict time schedules and occupy space over a predetermined and limited period of time after which the collection has to be removed and new items are put in place. If for any reason the producer is unable to meet the deadline for delivery, the only alternative is to ship via air, which is very expensive, otherwise delay can lead to discounts or cancellation of orders. 
In general, dealing with problems of this type is not always possible through allowing for lead time because the fast response on behalf of the firm to new orders - a primary factor in determining competitiveness on world markets - leaves almost no room for strategies of this kind. Even if possible is not without a cost. Making sure inputs arrive and cleared within a period that prevents delay of production requires a lead time of three months as a result of which firms incur storage and warehousing cost. Besides some types of imported inputs cannot be stocked because they are specific to the order being manufactured. For example, orders can differ in the type or specifications of yarn to be used, the kind of information that is not known until the order takes place. Stocking will therefore involve substantial risk. In some cases, labels and buttons have to carry the brand name of the product and hence cannot be imported except after the order is accepted.

Several procedures have to be completed before tariffs and sales taxes are refunded. A committee from the ministry of industry has to inspect the inputs on factory site and determine percentage of inputs that will be used in each product produced. It is often the case that these percentages are not consistent with those estimated by the firms according to the sizes adhered to. Also little allowance is made for the fact that part of raw material or fabric is typically wasted in the course of production. Percentages allowance for waste are arbitrary calculated despite the fact that technically they should vary according to sizes, models, and type of machinery. At one point and in response to complaints by some knitting firms, the allowable waste rates were raised from $30 \%$ (uniform) to $40-45 \%$ for firms in this area. The new rates were not applied in retrospect implying that the previous amounts of money paid as tariffs and taxes that were not refunded because of applying lower waste rates cannot be still refunded.

However, arbitrariness in estimating allowable waste rates is an issue that remains subject to complaints by firms. Every time a new product is produced, new percentages for allowable waste rates must be estimated and consequently all the above problems are likely to be repeated. Meanwhile, complaints that percentages are sometimes different between two firms with same product and inputs and same type of machinery, which is, not only evidence of arbitraness but also provides a clue to the extent of discretionary power enjoyed by officials in this institution. This is the second occasion - given temporal specificity- where the system invites opportunism. Several visits can take place as disputes arise, as a result of which time and costs are wasted. The report of the industrial committee, which has to be delivered directly to the headquarters of the Drawback and temporary admission office usually, takes a long time, on average two to three months. Completing the remaining export procedures is consequently delayed.

Right before exporting members from the general authority for importing and exporting and Drawback and temporary admission office has to inspect the export shipment to make sure that the same quantity and type of inputs imported were actually used in production of the good to be exported. Traditionally this used to take place through visual comparison of the inputs that were used in the final product with the sample drawn from the imported inputs at the time of import clearance. Recently, this was replaced by a much complicated procedure that requires the final product to be chemically analyzed adding an extra cause of delay and a cost of 500 L.E per consignment.

After the products have been exported, producers are eligible for a refund once the final procedures of the system are completed. A common cause of delay is that several documents are required to proceed with refunds. Two much details in the documents required increases the scope of errors, which in turn becomes a source of disputes, criminal and financial penalties and delay.

To mention but a few examples, an input that appears under an abbreviated name in one document while unabbreviated in anther can be considered a different input. The firm must provide documents from the supplier to clear such a matter. One frequent issue leading to disputes is when part of the output has not been exported because it is defected and must be visually inspected. Side payments are often one way to avoid such disputes. Calculating refunded taxes is a very complicated process particularly when more than one input consignment must be considered for one export shipment. Moreover, the number of employees handling this process is not enough to accommodate the number of firms and consignment in a timely fashion.

According to the law, funds should be refunded at most after one month. Some firms receive refunds within the specified time, but only after a great deal of effort is expended. Others receive a refund after a period as long as a year and a half. One can imagine the cost incurred in the form of interest payment if these are borrowed funds. One 
can imagine also the extent of the credit constraint facing small scale firms that now have to borrow huge amounts of funds to satisfy their working capital requirement if they are ever to export.

Refund takes place after the preliminary estimation is completed upon which the whole matter is then delegated to the accounting department in the custom office for the final auditing of the firms documents and books. ${ }^{3}$ The purpose of this step is a final check on the accuracy of the refunded amounts. This requires visits by members from the accounting department to the company. There is a long waiting period before this visits takes place, sometimes over a year. One reason for delay stems from the small number of auditors relative to the growing number of firms in this sector.

Disputes arise if some of the firm's documents or books are not complete or not in conformity - in form with what the custom auditors have in mind. Several visits takes place before these matters are resolved. Any sort of violation to the temporary admission and Drawback rules detected during the auditing process subjects the firm to financial and until very recently criminal penalties. Violations occur as a result of the firm - as appearing in it records - claiming amounts in refund larger than what is assessed by the auditors. According to the firms, such discrepancies can be due to unintended errors in registering weights or types of some raw material with varying prices. In some occasions, an expensive type of yarn is registered in the firm books at a lower price than its import price, these mistakes result in the firm refunding an amount less than what it is eligible for and yet both criminal - when effectiveand financial penalties apply.

Because the financial penalties accrue to the auditors as incentives, unintended mistakes are frequently considered intended. To settle these disputes, the firm will have to pay tariffs and sales taxes on all inputs not used in the products being exported in addition to fines. Anther option is to Petition to the minister. The remaining alternative is to take the case to court, which only extends the period of delay in addition to the costs of litigation.

In the meantime, and until the dispute is resolved, the entire importing and exporting business of the firm is adversely affected and disrupted. Under such circumstances, firm best bet is to settle and pay the fines. Once more, the system provides ample room for the executors to exercise opportunism and increase transaction costs. Expansion is rendered risky under these circumstances since the loses due to disruption in the firm activities until disputes are resolved increases the larger are these activities. The larger the loses, the greater is the potential of the 'hold up' problem and in turn transaction costs.

All this provides evidence to the extent to which transaction costs reduces the effectiveness of one of the few export incentives introduced and acts as a constraint to expansion in export activities.

High transaction costs greatly reduce the potential for exporting to the EU market. Firms are likely to loose EU clients since time restrictions are very binding for this market. On one hand, because it is fashion sensitive, styles are difficult to produce and on the other hand are difficult to stock since they change from season to season as fashion changes. Thus, orders are generally small in volume and delivery must take place within a relatively short period of time compared to markets like the U.S. Transaction costs, increases costs of production, reduces ability of firms to compete under tight time restriction, customers are lost as result and therefore - that is transaction costs - is considered one main factor preventing firms from increasing output to exploit economies of scale.

\section{CONCLUSION}

This paper showed that most of the problems facing producers in the textile and ready made garment industry are cyclical in nature. The most important of these problems are competition from smuggled imports and the recession in the domestic market. The main reason why producers were unable to compete with smuggled imports is tariffs and other taxes on imported intermediate inputs. Although some producers were able to cope with competitive pressures arising due to these factors through searching for new market niches, moving up market or exporting most of the firms surveyed believe that competing with imports from the EU will be difficult if not impossible as long as 
they continue to be denied access to duty free imported inputs.

As long as the current custom legislation, which provide ample room for custom clearance officers to exercise opportunism continue to exist, temporal specificity will lead to high transaction costs and will increase the cost of imported inputs and hence adversely affect competitiveness of producers in both the domestic and foreign market. Under these circumstances, the private cost and benefit of adjustment will diverge from the social cost and benefits and hence adjustment costs will be high. In particular, firms will be forced to exit or request protection rather than revitalize which is the socially optimal adjustment strategy given the cyclical nature of most of the problems described above.

In light of the above considerations, little merit is found in the provision, which allows for a transitional period until tariffs on imports of the textile and ready made garment from the EU falls to zero. Most of the constraints that will impede efficient adjustment discussed in this paper are inherent in the economic environment within which firms operate. These problems can be solved only through government intervention. In particular, customs laws, have to be revised in order to reduce the scope for exercising opportunism by both the importer and the custom officer. Finally, although the government reform program will certainly help reduce the severity of these constraints, it requires a substantially long time to be implemented. An alternatively faster and cheaper way to get around these problems is trade liberalization.

\section{NOTES}

1. For some types of inputs like sewing needles where breakage occurs very frequently, these taxes can be very burdensome.

2. Based on an interview with some custom officers conducted by Dr Omneya Helmy

3. This step was cancelled, but only recently

\section{REFERENCES}

1. Abdel Hakim, R. Effects of the Egypt -EU Partnership Agreement on the Textile Industry. The Egyptian Centre for Economic Studies. Working Paper No. 15. July, 1997

2. CAPMAS, Census for Population, Housing and Establishments 1996. CAPMAS Arab Republic of Egypt. 1997.

3. CAPMAS. Actual Production, Excess Capacity and Inventory in Manufacturing Industries. CAPMAS Arab Republic of Egypt. June 2001.

4. Economic Council of Canada.. Adjustment Policies for Trade Sensitive Industries. A research report prepared for the Economic Council of Canada. Canada. 1988

5. El-Gillany, M. Privatization in the Textile Sector. Paper Presented in The Conference for The effect of the Privatization Program on the Egyptian Economy. October 2002. Cairo, Egypt.

6. Elshennawy, Abeer.. The Transitional Costs to Trade Liberalization. An Intertemporal General Equilibrium Model for Egypt. Unpublished Ph.D. Dissertation. Department of Applied Economics. The University of Minnesota. U.S.A. 1998.

7. Fawzy, Samiha. and Nada Masoud. The future of Egypt's Exports of Textile and Ready Made Garment Industry. The Egyptian Centre for Economic Studies,Cairo, Egypt. Paper Number 86. June 2003.

8. Helmy, Omneya. Modernizing Customs Administration in Egypt. The Egyptian Center for Economic Studies, Cairo, Egypt. Working paper No. 81. April 2003.

9. Kheir El Din, H. and Hoda El Sayed. Potential Impact of a Free Trade Agreement with the EU on Egyptian Textile Industry. The Egyptian Centre for Economic Studies.Cairo, Egypt Working Paper No. 16. September, 1997.

10. Masten E. Scott and Crocker J. Keith.. Efficient Adaptation in long Term Contracts: Take or Pay Provisions for Natural Gas. American Economic Review, 75(5), December, 1985.pp 1083-93.Reprinted in Oliver E. Williamson and Scott E. Masten (eds). The Economics of Transaction Costs. An Elgar Critical Writings Reader. Cheltenham, UK. Northamption, MA, USA. 1999. 
11. Masten E. Scott, Meehan W. James and Snyder A. Edward. The Costs of Organization. Journal of Law, Economics and Organization, 7(1), Spring, 1991.pp1-25. Reprinted in Oliver E. Williamson and Scott E. Masten (eds). The Economics of Transaction Costs. An Elgar Critical Writings Reader. Cheltenham, UK. Northamption, MA, USA. 1999

12. Papageorgiou,D., Michaely, M., and A.M. Choksi eds. Liberalizing Foreign Trade. Lessons of Experience in the Developing World. Volume 7. Basil Blackwell. 1991

13. Mussa, M.. The Adjustment Process and the Timing of Trade Liberalization. National Burearu of Economic Research. Working Paper No. 1458. 1984

14. Patrick, H. Concepts, Issues, and Selected Findings. In Hugh Patrick and Larry Meissner eds. Pacific Basin Industries in Distress. Structural Adjustment and Trade Policy in the Nine Industrialized Economies. New York Columbia University Press. 1991.

15. Refaat, A. Trade Induced Protectionism in Egypt's Manufacturing Sector. The Egyptian Centre for Economic Studies. Working Paper No. 85. June 2003

16. Williamson E. Oliver. The Economic Institutions of Capitalism. New York. The Free Press. 1985.

\section{NOTES}


International Business \& Economics Research Journal - September 2007

Volume 6, Number 9

\section{NOTES}

